Browse $\vee^{\text {My Settings }} \stackrel{\text { Help }}{\text { Institutional Sign In }}$
Institutional Sign In

All

Conferences > 2021 th International Confer..

\section{Teaching Ethics to Engineering Students: Case Studies}

Publisher: IEEE

\section{Cite This}

Alfredo Soeiro ; Luis A. Oliveira

All Authors

8

Full

Text Views
Bरㅜㄷㄴ

PDF

\section{Alerts}

Manage

Content Alerts

Add to Citation

Alerts

\section{Need Full-Text} access to IEEE Xplore for your organization?

CONTACT IEEE TO SUBSCRIBE >

\section{More Like This}

Making sense of ethics in engineering education: A discursive examination of students' perceptions of work and ethics on multidisciplinary project teams 2014 IEEE International Symposium on Ethics in Science, Technology and Engineering

Published: 2014

Drafting a code of ethics for

2015 IEEE Frontiers in Education Conference (FIE)

Published: 2015 engineering education

\section{Abstract:}

Manuscripts'

Peer Review

IV. Case Study in Construction Management

Two case studies are presented and discussed as a means of implementing the teaching of ethics in two different contexts of engineering activity: scientific research and daily practice. One case study is related to the discipline of "Research Methodologies" for students of MSc and PhD degrees in the Initiative "Energy for Sustainability" (EfS) at the University of Coimbra,

V. Concluding Remarks Portugal. The second case study presented is related to the discipline of Construction Management of a master degree in Civil Engineering. The methodology applied during the teaching component comprises the description of Deontology and of Ethics. Professional engineering standards

Authors and practices are also presented and discussed. Problems with issues involving ethical decisions in construction management are described.

References Students are invited to discuss and to present their points of view. Groups are formed and discussions about conclusions of the group and global debates

Keywords take place. Disagreements or agreements are presented by each one supported by a rationale. Students are then faced with a methodology to support decision making in situations with an ethical essence. The methodology does not present a unique solution but addresses the ethical problem under three perspectives. The perspectives for ethical analysis are called reversibility, disclosure and impact. 
Published in: 2021 4th International Conference of the Portuguese Society for Engineering Education (CISPEE)

Date of Conference: 21-23 June 2021 DOI:

10.1109/CISPEE47794.2021.9507205

Date Added to IEEE Xplore: 11

August 2021

Publisher: IEEE

ISBN Information:

Conference Location: Lisbon, Portugal

\section{:三 Contents}

\section{Introduction}

Teaching ethics is increasingly acknowledged as paramount in the education of future engineers. In fact, engineering activities are of great impact to society. Engineering profession is regulated and controlled by several entities. These entities include professional organizations, government agencies,

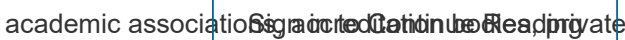
organizations and chambers of commerce. The result is a rich set of rules and recommendations to ensure quality of the engineering activities. The most common ones are deontological codes that define frameworks of the engineering performances.
4IEEE

\section{Publish Open Access} with IEEE

\section{Maximize visibility via \\ IEEE Xplore \\ Rapid decisions \\ Rigorous peer-review \\ Mandate-compliant}

IEEE Open Access options:

2 IEEE Access $^{B}$

(6) multidisciplinary journal

20+ Fully Open Access

Topical Journals

2 160 Top-cited

\% hybrid publications

Submit your paper today!

\section{Authors}

References

Keywords

Metrics

\section{CHANGE USERNAME/PASSWORD}

\section{PAYMENT OPTIONS}

VIEW PURCHASED DOCUMENTS
COMMUNICATIONS PREFERENCES

PROFESSION AND EDUCATION

TECHNICAL INTERESTS
US \& CANADA: +1800678

4333

WORLDWIDE: +1 732981 0060

CONTACT \& SUPPORT

About IEEE Xplore Contact Us Help Accessibility Terms of Use Nondiscrimination Policy IEEE Ethics Reporting [ Sitemap Privacy \& Opting Out of Cookies

\footnotetext{
IEEE Account

Change Username/Password

Update Address
}

Purchase Details
»Payment Options
»Order History

Profile Information

»Communications Preferences

»Profession and Education
Need Help?

US \& Canada: +1 8006784333

Worldwide: +17329810060 
About IEEE Xplore Contact Us Help Accessibility Terms of Use Nondiscrimination Policy Sitemap Privacy \& Opting Out of Cookies

A not-tor-profit organization. IEEE is the world's largest technical professional organization dedicated to advancing technology for the benefit of humanit)

(c) Copyright 2021 IEEE - All rights reserved. Use of this web site signifies your agreement to the terms and conditions. 